\title{
Iron ore-coal composite pellets/briquettes as new feed material for iron and steelmaking
}

\begin{abstract}
India becomes $3^{\text {rd }}$ largest steel producer in the world during 2015. But per capita consumption of steel in India continues to be as low as $60.6 \mathrm{~kg}$ only, against that of world average of around $208.6 \mathrm{~kg}$. There are potential for growth and vast domestic demand. It is likely to increase $95 \mathrm{~kg}$ by 2020 and $150 \mathrm{~kg}$ by 2030 . India's goal is 300 million tones $(\mathrm{Mt})$ steel production by 2030. Raw materials requirement are also increased with increasing steel production. For 300Mt per year steel production, processed iron ore requirement will be $486 \mathrm{Mt}$ per year; at this rate iron ore can last for another 10-12 years only. To reach $300 \mathrm{Mt}$ by 2030 , utilization of raw materials will be done properly and precisely; otherwise there will be shortage of raw materials in near future. To preserve the iron ore, secondary sources like ore fines, mill scale, slime and low grade iron ore (after beneficiation) can be utilized. These shall not only improve the reserves position, to the tune of about $10-15 \%$, by extracting metal is of vital concern for resource conservation and pollution control. The best option is to convert the iron ore and coal/coke fines into cold bonded iron ore-coal composite pellets/briquettes. By producing composite pellets/briquettes from iron ore and coal/ coke fines, utilization of these fines also takes place.
\end{abstract}

\author{
Volume I Issue I - 2017
}

\section{Dutta SK}

Department of Metallurgical and Materials Engineering, MS University of Baroda, India

\begin{abstract}
Correspondence: Dutta SK, Former Professor and Head, Department of Metallurgical and Materials Engineering, Faculty of Technology \& Engineering, M S University of Baroda, India,
\end{abstract} Email drskdutta1981@gmail.com

Received: March 03, 2017| Published: July 06, 2017

\section{Introduction}

Liberalization and opening up of the Indian economy has resulted in the increase of steel production. Indian steel industry has acquired a significant status and is currently ranked as the $3^{\text {rd }}$ largest steel producer in the world. India achieved a production of 89.4 million tones (Mt) of crude steel during 2015. This makes India the $3^{\text {rd }}$ largest global crude steel producer during 2015 as against the $4^{\text {th }}$ rank earlier. The finished steel use in India has increased significantly $(22.5 \%)$ from a level of around $64.9 \mathrm{Mt}$ in 2010 to $79.5 \mathrm{Mt}$ in $2015 .{ }^{1}$ Consumption of finished steel was increased average $4.2 \%$ from 2011 to 2015 , on the same period steel production increased about $6 \%$ as shown in Table 1.

But per capita consumption of steel in India continues to be low at $60.6 \mathrm{~kg}$ only (increased $14.8 \%$ with respect to 2010 ), against that of world average of around $208.2 \mathrm{~kg}^{1}$ and that of other developed countries average of around $300 \mathrm{~kg}$, indicates that India have miles to go in terms of attaining leadership in this critical area. Through Indian per capita steel consumption is relatively low yet the potential for growth, given the vast domestic demand, is immense. It is likely to increase to $95 \mathrm{~kg}$ by 2020 and $150 \mathrm{~kg}$ by 2030 . However, compared to the vast potential of the Indian rural market, domestic steel consumption has been on the lower side.

Table I Indian crude steel production and finished steel consumption
In 2015 world steel production by oxygen furnace (BOF) was $74.4 \%$, while production through electric furnace (EAF) was $25.1 \%$ and the rest $0.5 \%$ from open hearth furnace and others processes. ${ }^{1}$ It is expected that the steel production through the blast furnace (BF)-BOF route will increase or at least maintain its share, as the steelmaking capacity in major steel producing countries are largely $\mathrm{BF}$ based. The remaining production is likely to be through the EAF route based on scrap and sponge iron, the later requiring non-coking coal as the reductant and fuel.

India is endowed with abundant Iron ore resources, the basic input for steel making. Of late, large scale exports of iron ore have raised concerns about future availability of iron ore resources to meet the fast rising Indian steel demand. Large quantities of iron ore fines are exported due to mismatch between domestic production and consumption and also lack of adequate sintering and pelletization facilities for steel making. Steel industry confronts the problem of depletion of high grade ore deposits and lack of India's technological capabilities to process low grade iron ores. In the larger national interest of conservation of natural resources and environment, efforts are being made to preserve and utilize the precious iron ore fines for India's production of steel. ${ }^{2}$

\begin{tabular}{llllllll}
\hline & \multicolumn{2}{l}{ Crude steel production, Mt } & \multicolumn{3}{l}{ Finished steel consumption, Mt } \\
\hline Year & World & India & Indian growth rate per year, \% & World & India & Indian growth rate per year, \% \\
\hline 2010 & 1433 & 66.9 & & 1310.5 & 64.9 & \\
2011 & 1538 & 73.5 & 9.9 & 1415.4 & 69.8 & 7.6 \\
2012 & 1560 & 77.3 & 5.2 & 1443.7 & 72.4 & 3.7 \\
2013 & 1650 & 81.2 & 5 & 1534.2 & 73.7 & 1.8 \\
2014 & 1670 & 87.3 & 7.5 & 1546.9 & 76.1 & 3.3 \\
2015 & 1621 & 89.4 & 2.4 & 1500.1 & 79.5 & 4.5 \\
Average & & & 6 & & & 4.2 \\
\hline
\end{tabular}


Against good iron ore deposits in India, the situation in regard to coking coal is not very satisfactory. The depleting resources of coking coals, the world over and especially in India, are posing a threat to the conventional blast furnace route of iron making. Again a lot of coal fines and coke breeze are also produced during coal mining and coking of coal respectively. Utilization of iron ore and coal fines for extracting metal is of vital concern for resource conservation and pollution control. The other option is to convert the iron ore and coal/coke fines into composite pellets/briquettes. By producing iron ore-coal/coke composite pellets/briquettes from iron ore and coal/ coke fines, utilization of these fines takes place as well as new feed materials are generated for iron and steel making.

\section{Raw materials}

\section{Iron ore}

Total iron ore resources in India are about 28.52billion tones (Bt). The total resources of hematite and magnetite in the country (as on 1.4.2010) are estimated at $17,882 \mathrm{Mt}$ and $10,644 \mathrm{Mt}^{3}$ About $57 \%$ of iron ore production comes in the form of fines (including concentrates) during course of mining operations itself. About 30\% low grade iron ore of total reserve is available for supply to contribute in the demand of Indian Iron and Steel Industries. About $70 \%$ of the total production of the country's iron ore is fines.

Around 4Mt of fine slimes (containing 55 to $60 \%$ iron) are generated every year by ore washing plants in India. ${ }^{4}$ Mill scales are also the industrial by-product, which are produced due to hot working processes (such as hot rolling, forging and heat treatment of steel etc). At present, most of the slimes and mill scales are thrown away as waste for land filling and create pollution to the environment, which are not desirable. Utilization of these fines for extracting metal is of vital concern for resource conservation and pollution control.

\section{Coal}

Coal is the most widely used energy source for electricity generation and an essential input to most steel production. As estimated by the World Coal Association, coal currently fuels $41 \%$ of the world electricity and this proportion is set to remain static over the next 30 years. About $70 \%$ of the world's steel production is based on coal. As per Integrated Energy Policy Committee of Planning Commission, coal will remain India's most important energy source till 2031-32 and possibly beyond.

Coal reserves are estimated by Geological Survey of India (GSI) as on 1.4.2014 of which the prime coking coals are 5.31Bt, medium coking and semi-coking are $28.38 \mathrm{~B}$ and non-coking coals are $266 \mathrm{Bt}^{5}$ Large amount of coal fines and coke breezes are also generated during coal mining and coking of coal respectively. Due to the very nature of deposition, Indian coals, in general, are of inferior quality owing to high ash percentage. Therefore, Indian steel industries will remain depended on coal imports particularly for low ash coking coals. ${ }^{3}$

The domestic availability of coking coal, a critical raw material required by steel industry is limited and therefore the Indian steel industry has to depend heavily on imported coking coal to meet its needs. Currently, domestic steel makers meet $70 \%$ of their coking coal requirement through imports. ${ }^{2}$ Non-coking coal used for production of sponge iron is also increasingly becoming scarce in India. With the demand for non-coking coal from priority sectors like power, fertilizers etc going up further, its availability for steel making is likely to be limited during the coming years. While sponge iron producers may opt for import of coal, the economic viability of this sector may be under pressure due to higher prices of imported coal. Moreover, the gas based sponge iron units face restricted supply of compressed natural gas $(\mathrm{CNG})$, largely due to priority allocation of gas to power and fertilizer sectors. Supply of CNG to this sector is a major concern for its growth and these units may have to depend more on imported source of fuel supply.

\section{Composite pellets}

In order to utilize these fines efficiently and economically, a novel concept of cold bonding technique is developed. In the cold bonding concept, the fines of iron bearing oxides and carbonaceous materials are mixed with a suitable binder and optimum quantity of moisture. The mixture is then pelletized into balls of appropriate size. In cold bonding process, the composite pellets are hardened due to the physico-chemical changes of the binder in ambient conditions or at slightly elevated temperature $\left(120\right.$ to $\left.220^{\circ} \mathrm{C}\right)$. The challenge in cold bonding process is to find a good binder that ensures the proper physical and mechanical properties of the composite pellets. Cold bonded composite pellets also utilize cheap and readily available reductant such as coal fines, coke breeze, and char fines. ${ }^{6}$

Interest in iron ore-coal composite pellets has grown from the decade of 1980s because of the following advantages: ${ }^{7}$

a. Utilization of cheaper resource such as iron bearing fines, coal fines, coke breeze etc. and for pollution control,

b. Very fast reduction due to intimate contact between reductant and oxide particles,

c. Induration of pellets is an energy consumption process, as cold bonded composite pellets do not require induration, energy can be saved;

d. Promising prospect for iron making at small scale with higher production rate,

e. Because of their uniform size and convenient form, pellets can be continuously charged into the furnace leading to higher productivity, and

f. Consistent product quality as the chemical composition of composite pellets (input material) does not change.

\section{Binders}

Binders must satisfy the following requirements: ${ }^{8}$

a. Mechanical properties: A good binder should maintain good mechanical properties of pellets, including green, dry and fired pellets, e.g., deformation under load, resistance to disintegration/fracture by compression and impact, resistance to abrasion, superior compressive strength etc.

b. Chemical composition: A good binder should bring no environmentally and metallurgically harmful elements such as $\mathrm{P}, \mathrm{S}$ and As etc into product pellets. It should not increase impurities such as silica.

c. Metallurgical performance: A good binder should maintain pellet's excellent metallurgical properties, such as high reducibility, little swelling, and little pressure drop during reduction. 
d. Processing behaviour: Adding, mixing, dispersion of binder, green ball preparation, pellet drying, etc., should not be complicated or essentially change conventional pellet production circuit. It should possess good thermal stability.

e. Cost factor: Price of binder should be acceptable for pellets production. It should be cheap and easily available in the market.

Different types of binders are used by research workers for iron ore-coal composite pellet making. Bentonite, cement, sponge iron powder, lime, hydrated lime, and silica have been employed as inorganic binders whereas starch based binders; dextrin, molasses, dextrose and oil-slush are some of the organic binders.

The binders selected (by author and co-workers) ${ }^{6,8-11}$ for composite pellet making may be classified into three categories:

a. Inorganic binders: Lime $(\mathrm{CaO}), \mathrm{Ca}(\mathrm{OH})_{2}$, Slaked lime and fly ash were used.

b. Organic binders: Dextrose, Molasses, and Sodium Polyacrylate (SPA) were employed.

c. Different combination of inorganic-organic binders were employed:

$\mathrm{CaO}+$ Dextrose, $\quad$ Slaked lime + Dextrose, $\mathrm{CaO}+$ Slaked lime+Dextrose, $\mathrm{Ca}(\mathrm{OH})_{2}+$ Molasses, Slaked lime + Molasses, SPA+Slaked lime, Fly Ash+Slaked Lime+Molasses etc. Selection of binder, binding mechanism, reduction behaviour, kinetic studies and further technologically related to composite pellets can be found out elsewhere. ${ }^{6,8-11}$

\section{Composite pellet/briquette preparation}

To select the proper binder, initially briquettes of iron ore-coal composite were prepared. Figure 1 shows the flow diagram for composite briquette/pellet making. ${ }^{6}$ Iron ore-coal composite pellets were prepared using binder which was selected on the basis of briquettes formation and strength of briquettes.

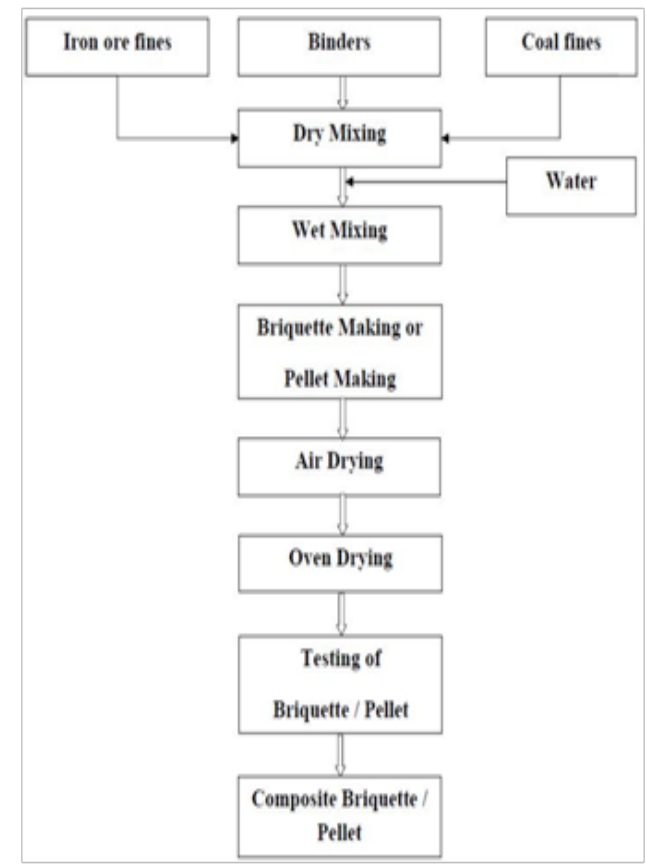

Figure I Flow diagram for composite briquette/pellet making.

\section{Results}

Results of composite pellets are shown in Table 2, the compressive strength values of different binder group are acceptable values for commercial use (more than $150 \mathrm{~N}$ per pellet).

It was observed that the average compressive strength of both ACP [high ash content (35.65\%) coal] and BCP [low ash content $(14.67 \%)$ coal] composite pellets increased with increasing $\mathrm{Fe}_{\text {tot }} / \mathrm{C}_{\mathrm{fix}}$ ratio as shown in Figure 2. This may be attributed to the higher ratio of iron to carbon as well as more amount of binder in pellets. Further, the compressive strength of $\mathrm{BCP}$ pellets were found higher than ACP pellets for corresponding $\mathrm{Fe}_{\text {tot }} / \mathrm{C}_{\text {fix }}$ ratio which may be attributed to the relatively higher amount of binder as well as low porosity.

The shatter index values were observed decreasing with increasing $\mathrm{Fe}_{\text {tot }} / \mathrm{C}_{\text {fix }}$ ratio in both ACP and BCP pellets as shown in Figure $3 .{ }^{6}$

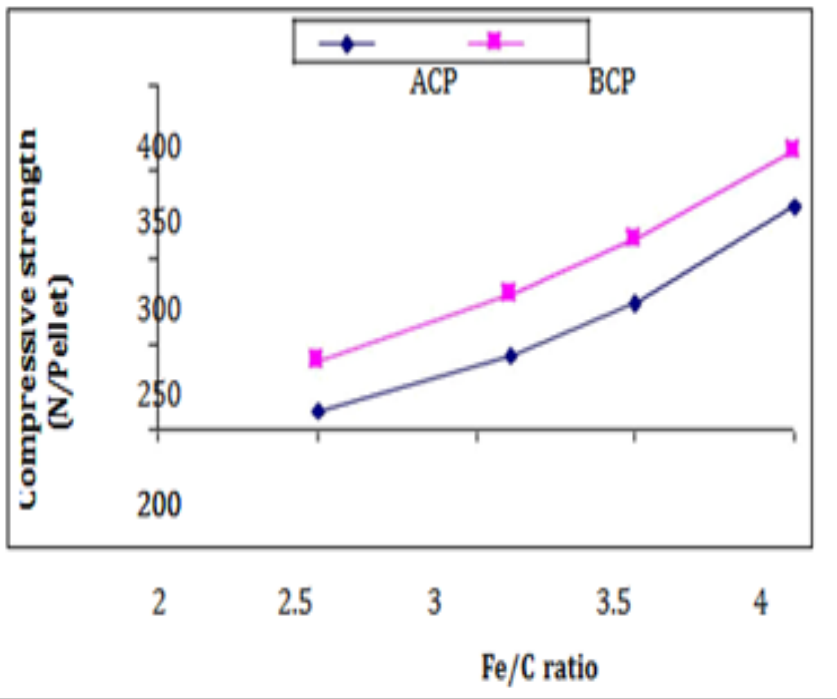

Figure 2 Compressive strength vs Fe/C ratio plot for pellets.

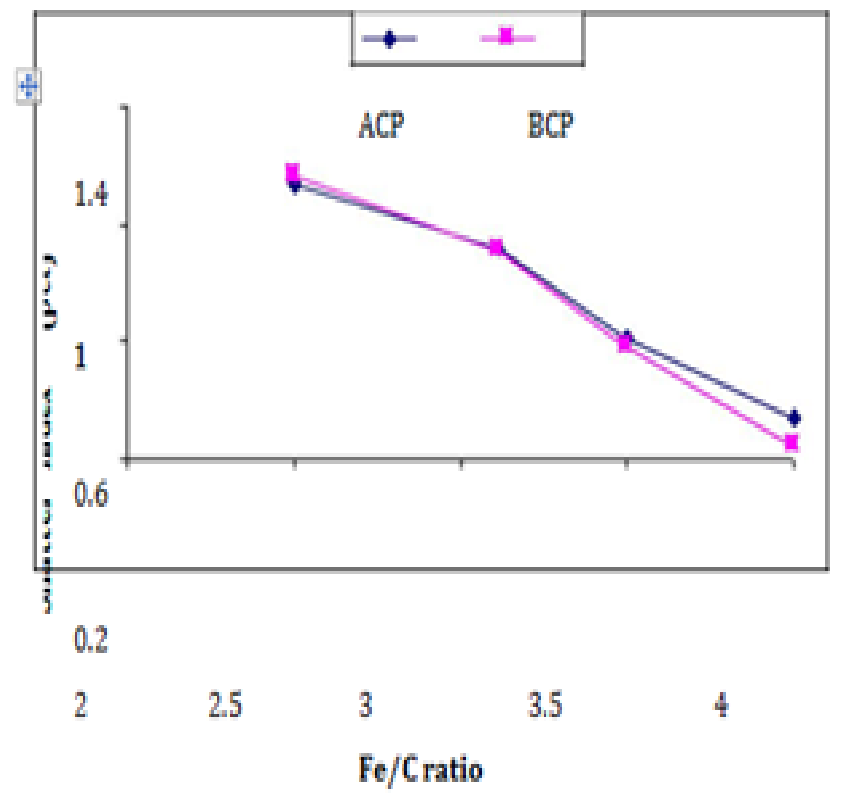

Figure 3 Shatter index vs Fe/C ratio plot for pellets. 
Table 2 Properties of composite pellets

\begin{tabular}{|c|c|c|c|c|c|}
\hline Sr. no. & Binder & $\begin{array}{l}\mathrm{Co}_{2} \text { gas } \\
\text { passed }\end{array}$ & $\begin{array}{l}\text { Compressive strength* } \\
\text { (N/Pellet) }\end{array}$ & Shatterindex(\%) & $\begin{array}{l}\text { Dry drop strength* } \\
\text { (Numbers) }\end{array}$ \\
\hline 1 & $\begin{array}{l}\text { Fly Ash-N+Slaked } \\
\text { Lime+Molasses }\end{array}$ & Yes & 216 & 0.84 & 64 \\
\hline 2 & $\begin{array}{l}\text { Fly Ash(II)+Slaked } \\
\text { Lime+Molasses }\end{array}$ & Yes & 168 & 0.94 & 13 \\
\hline 3 & $\begin{array}{l}\text { Fly Ash-N+Slaked } \\
\text { Lime+Molasses }\end{array}$ & No & 148 & 1.39 & 47 \\
\hline 4 & $\begin{array}{l}\text { Fly Ash-W+Slaked } \\
\text { Lime+Molasses }\end{array}$ & No & 130 & 0.44 & 26 \\
\hline 5 & $\begin{array}{l}\text { Fly Ash(II)+Slaked } \\
\text { Lime+Molasses }\end{array}$ & No & 156 & $0.7 \mathrm{I}$ & 40 \\
\hline 6 & $\begin{array}{l}\text { Fly Ash }(I)+\text { Slaked } \\
\text { Lime+Molasses }\end{array}$ & Yes & 130 & 1.48 & 46 \\
\hline 7 & Dextrin+Calcium Hydroxide & Yes & 126 & 0.78 & 165 \\
\hline 8 & Polyvinyl Alcohol (powder) & No & 282 & 0 & 104 \\
\hline 9 & Polyvinyl Alcohol (solution) & No & 362 & 0.1 & 159 \\
\hline
\end{tabular}

\section{Conclusions}

The gradual depletion of high-grade iron ores has necessitated the exploitation of low grade iron ore reserves of India. As the beneficiation processes are energy intensive and altering economics of products. Low grade iron ore can be upgraded by beneficiation process. India is also fortunate for having vast amount of coal. Non coking coal fines and coke breeze can be utilized by iron ore-coal/ coke composite briquette/pellet technology. Utilization of these fines (iron ore and coal/coke) by producing composite briquette/pellet for extracting metal is of vital concern for resource conservation and pollution control. The iron ore-coal/coke composite briquette/pellet can be acted as new feed materials for iron and steel making. Since composite briquette/pellet have very fast reduction rate due to intimate contact between reductant and oxide particles, hence productivity of iron and steel making has drastically increased.

\section{Acknowledgements}

None.

\section{Conflict of interest}

The author declares no conflict of interest.

\section{References}

1. World Steel in Figures. World Steel Association. 2016.
2. https://mme.iitm.ac.in/shukla/wg_steel2212\%281\%29.pdf

3. http://steel.gov.in/sites/default/files/MECON_Complete\%20Infra\%20 Report\%20for\%20300MT\%20Steel\%20by\%202015_7Jul15.pdf

4. Dutta SK. Utilization of Iron Ore and Coal Fines by Composite Pelletmaking. Iron \& Steel Reviews. 2016;60(2):111-115.

5. http://www.portal.gsi.gov.in/portal

6. Sah R, Dutta SK. Effects of binder on the properties of iron ore-coal composite pellets. Mineral Processing \& Extractive Metallurgy Review. 2010;31(2):73-85

7. Ghosh A, Kinetics. Mechanism of Reduction in Composite Iron OreReductant Pellets. Proc. Inter. Conf. on Alternative Routes of Iron and Steelmaking. Australia; Perth: 1999. p. 71-78.

8. Dutta SK, Sah R, Chokshi Y. Iron Ore - Coal / Coke Composite Pellets. Germany: Lambert Academic Publishing; 2013.

9. Dutta S.K, Ghosh A. Study of Non-isothermal Reduction of Iron OreCoal/Char Composite Pellets. Metall Mat Trans. 1994;25(1):15-26.

10. Sah R, Dutta SK. Iron ore-coal composite pellets preparation and their smelting kinetics. Proc of International Conference on Advances in Theory of Iron making \& steel making, IISc, Banglore, India; 2009. p. 93-100.

11. Chokshi Y, Dutta SK. Production of Iron Ore-Coal Composite Briquette/ Pellet by using Fly-ash and Other Binders. Proc of International Conference on Science and Technology of Iron making \& Steel making (STIS 2013), Jamshedpur, India; 2013. p. 16-18. 